\title{
Selected Soybean Plant Introductions with Partial Resistance to Sclerotinia sclerotiorum
}

D. D. Hoffman and B. W. Diers, Department of Crop Sciences, University of Illinois at Urbana-Champaign, Urbana 61801; G. L. Hartman, USDA-ARS and Department of Crop Sciences, University of Illinois; C. D. Nickell, Department of Crop Sciences, University of Illinois; R. L. Nelson, USDA-ARS and Department of Crop Sciences, University of Illinois; W. L. Pedersen, Department of Crop Sciences, University of Illinois; E. R. Cober, Eastern Cereal and Oilseed Research Center, Agriculture and Agri-Food Research Canada, Ottawa, Ontario K1A OC6, Canada; G. L. Graef, Agronomy Department, and J. R. Steadman, Department of Plant Pathology, University of Nebraska, Lincoln 68583; C. R. Grau, Plant Pathology Department, University of Wisconsin, Madison 53706; B. D. Nelson and L. E. del Rio, Department of Plant Pathology, and T. Helms, Department of Plant Sciences, North Dakota State University, Fargo 58105; T. Anderson and V. Poysa, Greenhouse and Processing Crops Research Center, Agriculture and Agri-Food Canada, Harrow, Ontario NOR 1G0, CANADA; I. Rajcan, Department of Plant Agriculture, University of Guelph, Guelph, Ontario N1G 2W1, Canada; and W. C. Stienstra, University of Minnesota, Minneapolis 55108

\section{ABSTRACT}

Hoffman, D. D., Diers, B. W., Hartman, G. L., Nickell, C. D., Nelson, R. L., Pedersen, W. L., Cober, E. R., Graef, G. L., Steadman, J. R., Grau, C. R., Nelson, B. D., del Rio, L. E., Helms, T., Anderson, T., Poysa, V., Rajcan, I., and Stienstra, W. C. 2002. Selected soybean plant introductions with partial resistance to Sclerotinia sclerotiorum. Plant Dis. 86:971-980.

Sclerotinia stem rot, caused by Sclerotinia sclerotiorum, is a major soybean (Glycine max) disease in north-central regions of the United States and throughout the world. Current sources of resistance to Sclerotinia stem rot express partial resistance, and are limited in number within soybean germ plasm. A total of 6,520 maturity group (MG) 0 to IV plant introductions (PIs) were evaluated for Sclerotinia stem rot resistance in the United States and Canada in small plots or in the greenhouse from 1995 to 1997. Selected PIs with the most resistance were evaluated for resistance in the United States and Canada in replicated large plots from 1998 to 2000. The PIs in the MG I to III tests in Urbana, IL were evaluated for agronomic traits from 1998 to 2000. The selected PIs also were evaluated with an excised leaf inoculation and petiole inoculation technique. After the 1995 to 1997 evaluations, all but 68 PIs were eliminated because of their susceptibility to Sclerotinia stem rot. In field tests in Urbana, higher disease severity in selected MG I to III PIs was significantly $(P$ $<0.05)$ associated with taller plant heights and greater canopy closure. All other agronomic traits evaluated were not associated or were inconsistently associated with disease severity. MG I to III PIs 153.282, 189.931, 196.157, 398.637, 417.201, 423.818, and 561.331 had high levels of resistance and had canopies similar to the resistant checks. The resistance ratings from the petiole inoculation technique had a high and significant $(P<0.01)$ correlation with disease severity in the MG I and II field tests. The partially resistant PIs identified in this study can be valuable in incorporating Sclerotinia stem rot resistance into elite germ plasm.

Additional keywords: disease evaluation, soybean germ plasm, soybean resistance, white mold

Sclerotinia stem rot, caused by Sclerotinia sclerotiorum (Lib.) de Bary, is a major soybean (Glycine max (L.) Merr.)

Corresponding author: B. W. Diers

E-mail: bdiers@uiuc.edu

A contribution of the University of Nebraska Agricultural Research Division, Lincoln 68583. Journal Series No. 13593.

Trade and manufacturers' names are necessary to report factually on available data; however, the USDA neither guarantees nor warrants the standard of the product, and the use of the name by USDA implies no approval of the product to the exclusion of others that may also be suitable.

Accepted for publication 7 May 2002.

Publication no. D-2002-0708-02R

(C) 2002 The American Phytopathological Society externally on stems and pods $(6,13)$. The fungus thrives in the north-central areas of the United States where cool, moist environmental conditions frequently occur $(17,20,27,28)$. Field conditions such as narrow row spacing $(14,16)$, irrigation (14), high plant populations (12), and lush vegetative growth (11) increase the likelihood of infections, because these variables promote shaded, moist, and cool canopy conditions conducive for infection.

Several researchers have developed and applied growthroom $(2,8)$, greenhouse $(8,19,23)$, and laboratory $(7,8,19,23,24,27)$ methods that detect significant $(P<0.05)$ differences for Sclerotinia stem rot reactions among genotypes, but it has been difficult to identify a method that produces reactions that consistently correlate with field results. Kim et al. (19) reported that disease reactions from infested oat seed, mycelial plug, and excised leaf inoculation methods were significantly $(P<0.05)$ correlated with field reactions for 18 cultivars with correlations ranging from 0.47 to 0.51 . Wegulo et al. (27) reported that disease reactions from a detached leaf assay, mycelial inoculation of foliage, and oxalic acid methods were significantly $(P<0.05)$ correlated with the field reactions for 12 cultivars with correlations ranging from 0.40 to 0.55 . Although moderate correlation values were found among inoculation methods by Kim et al. (19) and Wegulo et al. (27), better greenhouse and laboratory methods are needed to accurately predict the field reaction of soybean germ plasm to S. sclerotiorum.

Soybean cultivars have been identified with partial resistance to $S$. sclerotiorum in field evaluations $(14,18,20,24,27,30)$. The cultivars Corsoy, Corsoy 79, Hodgson 78, and Syngenta S19-90 (S19-90) consistently have expressed the most partial resistance of genotypes tested in several field evaluations $(14,18,20,27,30)$. Although partial resistance has been identified in soybean cultivars, current sources of resistance in commercial cultivars are limited, and these 
Table 1. Number of plant introductions (PIs), location of field evaluations, and identification of maturity group (MG) 0 to IV PIs evaluated by institutions and companies for Sclerotinia stem rot resistance from 1995 to 2000

\begin{tabular}{|c|c|c|c|c|c|}
\hline Year & MG & FC and PI number evaluated ${ }^{\mathrm{a}}$ & Total no. & Institution or company & Location \\
\hline \multirow[t]{9}{*}{1995} & 0 & FC 21.340 to PI $587.091^{\mathrm{b}}$ & 400 & University of Minnesota-Twin Cities & Staples, MN, USA ${ }^{\mathrm{c}}$ \\
\hline & & $\ldots$ & & University of Wisconsin-Madison & Galesville, WI, USA ${ }^{c}$ \\
\hline & I & FC 03.609 to PI 578.481 & 1,427 & Michigan State University & East Lansing, MI, USA ${ }^{\mathrm{c}}$ \\
\hline & & $\ldots$ & & University of Minnesota-Twin Cities & Staples, MN, USA ${ }^{c}$ \\
\hline & & $\ldots$ & & Stine Seed Co., Inc. & Millington, MI, USA \\
\hline & II & FC 01.547 to PI $578.473 \mathrm{~A}$ & 1,666 & Dairyland Seed Co., Inc. & Dansville, MI, USA \\
\hline & & $\ldots$ & & Michigan State University & East Lansing, MI, USA ${ }^{c}$ \\
\hline & & & & Stine Seed Co., Inc. & Millington, MI, USA \\
\hline & III & FC 21.108 to PI 578.366 & 1,454 & The Ohio State University & Marion, OH, USA \\
\hline \multirow[t]{14}{*}{1996} & 0 & FC 21.340 to PI $587.091^{\mathrm{b}}$ & 618 & Asgrow Seed Co. & Stewart, MN, USA \\
\hline & & $\ldots$ & & University of Guelph & Guelph, ON, Canada \\
\hline & & $\ldots$ & & University of Minnesota-Twin Cities & Staples, MN, USA ${ }^{\mathrm{c}}$ \\
\hline & & $\ldots$ & & University of Wisconsin-Madison & Hancock, WI, USA \\
\hline & I & Selected PIs from 1995 & 448 & Asgrow Seed Co. & Janesville, WI, USA \\
\hline & & .. & & University of Guelph & Guelph, ON, Canada \\
\hline & & $\ldots$ & & University of Minnesota-Twin Cities & Staples, MN, USA ${ }^{c}$ \\
\hline & & $\ldots$ & & Michigan State University & East Lansing, MI, USA ${ }^{\mathrm{c}}$ \\
\hline & II & Selected PIs from 1995 & 542 & Agricultural and Agri-Food Canada & Harrow, ON, Canada ${ }^{c}$ \\
\hline & & $\ldots$ & & Asgrow Seed Co. & Janesville, WI, USA \\
\hline & & $\ldots$ & & Michigan State University & East Lansing, MI, USA ${ }^{c}$ \\
\hline & III & Selected PIs from 1995 & 928 & Dairyland Seed Co., Inc. & Dansville, MI, USA \\
\hline & & $\ldots$ & & Michigan State University & East Lansing, MI, USA ${ }^{c}$ \\
\hline & & $\ldots$ & & Stine Seed Co., Inc. & Millington, MI, USA ${ }^{\mathrm{c}}$ \\
\hline \multirow[t]{17}{*}{1997} & 0 & Selected PIs from 1996 & 168 & University of Minnesota-Twin Cities & Staples, MN, USA ${ }^{\mathrm{c}}$ \\
\hline & I & Selected PIs from 1996 & 97 & Asgrow Seed Co. & Janesville, WI, USA \\
\hline & & $\ldots$ & & Michigan State University & East Lansing, MI, USA ${ }^{c}$ \\
\hline & & $\ldots$ & & Pioneer Hi-Bred Int., Inc. & Cedar Falls, IA, USA \\
\hline & & $\ldots$ & & Stine Seed Co., Inc. & Millington, MI, USA ${ }^{\mathrm{c}}$ \\
\hline & II & Selected PIs from 1996 & 40 & Asgrow Seed Co. & Janesville, WI, USA \\
\hline & & $\ldots$ & & Dairyland Seed Co., Inc. & Dansville, MI, USA ${ }^{\mathrm{c}}$ \\
\hline & & $\ldots$ & & Michigan State University & East Lansing, MI, USA ${ }^{\mathrm{c}}$ \\
\hline & & $\ldots$ & & Pioneer Hi-Bred Int., Inc. & Cedar Falls, IA, USA \\
\hline & & $\ldots$ & & Pioneer Hi-Bred Int., Inc. & Liberty Center, OH, USA \\
\hline & & $\ldots$ & & Stine Seed Co., Inc. & Millington, MI, USA ${ }^{\mathrm{c}}$ \\
\hline & III & Selected PIs from 1996 & 56 & Asgrow Seed Co. & Janesville, WI, USA \\
\hline & & $\ldots$ & & Dairyland Seed Co., Inc. & Dansville, MI, USA ${ }^{\mathrm{c}}$ \\
\hline & & $\ldots$ & & Michigan State University & East Lansing, MI, USA ${ }^{\mathrm{c}}$ \\
\hline & & $\ldots$ & & Pioneer Hi-Bred Int., Inc. & Cedar Falls, IA, USA \\
\hline & & $\ldots$ & & Pioneer Hi-Bred Int., Inc. & Liberty Center, OH, USA \\
\hline & & $\ldots$ & & Stine Seed Co., Inc. & Millington, MI, USA ${ }^{c}$ \\
\hline \multirow[t]{12}{*}{1998} & 0 & Selected PIs from 1997 & 21 & University of Guelph & Elora, ON, Canada \\
\hline & & $\ldots$ & & Agricultural and Agri-Food Canada & Ottawa, ON, Canada \\
\hline & I & Selected PIs from 1997 & 22 & University of Guelph & Elora, ON, Canada \\
\hline & & $\ldots$ & & Agricultural and Agri-Food Canada & Ottawa, ON, Canada \\
\hline & & $\ldots$ & & University of Illinois at Urbana-Champaign & Urbana, IL, USA \\
\hline & & $\ldots$ & & University of Minnesota-Twin Cities & Staples, MN, USA \\
\hline & & $\ldots$ & & University of Wisconsin-Madison & Madison, WI, USA \\
\hline & II & Selected PIs from 1997 & 4 & Agricultural and Agri-Food Canada & Harrow, ON, Canada \\
\hline & & $\ldots$ & & University of Guelph & Elora, ON, Canada \\
\hline & & $\ldots$ & & University of Illinois at Urbana-Champaign & Urbana, IL, USA \\
\hline & & $\ldots$ & & University of Wisconsin-Madison & Madison, WI, USA \\
\hline & III & Selected PIs from 1997 & 6 & University of Illinois at Urbana-Champaign & Urbana, IL, USA \\
\hline \multirow[t]{13}{*}{1999} & 0 & Selected PIs from 1998 & 21 & Agricultural and Agri-Food Canada & Ottawa, ON, Canada \\
\hline & & $\ldots$ & & University of Guelph & Elora, ON, Canada \\
\hline & & $\ldots$ & & North Dakota State University & Fargo, ND, USA \\
\hline & $\mathrm{I}$ & Selected PIs from 1998 & 22 & Agricultural and Agri-Food Canada & Ottawa, ON, Canada \\
\hline & & $\ldots$ & & University of Guelph & Elora, ON, Canada \\
\hline & & $\ldots$ & & University of Illinois at Urbana-Champaign & Urbana, IL, USA \\
\hline & & $\ldots$ & & University of Wisconsin-Madison & Arlington, WI, USA \\
\hline & II & Selected PIs from 1998 & 4 & Agricultural and Agri-Food Canada & Harrow, ON, Canada \\
\hline & & $\ldots$ & & University of Guelph & Elora, ON, Canada \\
\hline & & $\ldots$ & & University of Illinois at Urbana-Champaign & Urbana, IL, USA \\
\hline & & & & University of Wisconsin-Madison & Arlington, WI, USA \\
\hline & III & Selected PIs from 1998 & 6 & University of Illinois at Urbana-Champaign & Urbana, IL, USA \\
\hline & IV & Selected PIs from $1998^{\mathrm{d}}$ & 15 & University of Illinois at Urbana-Champaign & Urbana, IL, USA \\
\hline \multirow[t]{7}{*}{2000} & 0 & Selected PIs from 1999 & 21 & North Dakota State University & Fargo, ND, USA \\
\hline & I & Selected PIs from 1999 & 22 & Agricultural and Agri-Food Canada & Harrow, ON, CAN \\
\hline & & & & University of Illinois at Urbana-Champaign & Urbana, IL, USA \\
\hline & II & Selected PIs from 1999 & 4 & Agricultural and Agri-Food Canada & Harrow, ON, Canada \\
\hline & & $\ldots$ & & University of Illinois at Urbana-Champaign & Urbana, IL, USA \\
\hline & III & Selected PIs from 1999 & 6 & University of Illinois at Urbana-Champaign & Urbana, IL, USA \\
\hline & IV & Selected PIs from 1999 & 15 & University of Illinois at Urbana-Champaign & Urbana, IL, USA \\
\hline
\end{tabular}

a Maturity group 0 to IV PIs (PI and FC) obtained from the USDA Soybean Germplasm Collection in Urbana, IL.

${ }^{\mathrm{b}}$ Maturity group 0 plant introductions were subdivided into two groups and evaluated in 1995 (400) and 1996 (618).

${ }^{c}$ Location had a moderate to severe level of Sclerotinia stem rot infection and was utilized for selecting plant introductions with an equal level of resistance as Syngenta S19-90 during 1995-1997.

d Maturity group IV PIs were selected from greenhouse evaluations in Urbana, IL from 1996 to 1998. 
sources do not completely prevent yield loss $(17,30)$. Pennypacker and Risius (25) reported partial resistance is not stable in cultivars grown in different greenhouse environments, and Kim and Diers (18) found a significant $(P<0.05)$ genotype-environment interaction in a population of soybean genotypes evaluated in four Michigan environments. These results indicate the reaction of cultivars to $S$. sclerotiorum is influenced by environmental factors.

Researchers are beginning to explore variation within populations of S. sclerotiorum (21). Although no races of $S$. sclerotiorum have been established, isolates vary in aggressiveness (5). With the compounding factors of partial resistance in soybean and variation within S. scle-

Table 2. Field plot size, number of replications, irrigation status, and source of Sclerotinia sclerotiorum in eight environments utilized for testing maturity group 0 to IV soybean plant introductions and check cultivars during 1998 to 2000

\begin{tabular}{lcccccc}
\hline & \multicolumn{3}{c}{ Plot size } & & & \\
\cline { 2 - 5 } Environments & No. of rows & Width $(\mathbf{m})$ & Length $(\mathbf{m})$ & Replications & Irrigation $^{\mathbf{a}}$ & Source $^{\mathbf{b}}$ \\
\hline Arlington, WI, USA & 13 & 0.19 & 6.4 & 3 & N & PC \\
Elora, ON, Canada & 3 & 0.43 & 2.0 & 2 & OSM & S \\
Fargo, ND, USA & $2-3$ & 0.22 & 6.1 & $3-4$ & OSM & GG \\
Harrow, ON, Canada & 4 & 0.60 & 1.5 & 3 & OSM & S,GG \\
Madison, WI, USA & 13 & 0.19 & 6.4 & 3 & N & PC \\
Ottawa, ON, Canada & 4 & 0.40 & 2.0 & 2 & OSM & PC \\
Staples, MN, USA & 4 & 0.76 & 4.6 & 3 & OSM & PC \\
Urbana, IL, USA & 6 & 0.19 & 3.7 & 2 & OSM & GG \\
\hline
\end{tabular}

${ }^{a} \mathrm{~N}=$ plots were not irrigated, OSM = plots were irrigated by overhead sprinkling or misting.

${ }^{\mathrm{b}}$ Source of inoculum: $\mathrm{PC}=$ inoculum in soil from previous crops, $\mathrm{S}=$ sclerotia from field screenings of harvested common beans were spread on field and incorporated, GG = soaked grain (sorghum, wheat, and/or oat) infested with Sclerotinia sclerotiorum was dried, ground, and spread in the top of the soybean canopy.

rotiorum, identification of more sources of resistance is needed. Plant introductions (PIs) in the United States Department of Agriculture (USDA) Soybean Germplasm Collection are a potential source of new Sclerotinia stem rot resistance genes. The objectives of this study were to (i) evaluate soybean PIs to identify new sources of resistance to Sclerotinia stem rot, (ii) evaluate the agronomic characteristics of the most resistant PIs, and (iii) correlate field disease severity of the most resistant PIs with agronomic characteristics and results from greenhouse and laboratory resistance tests.

\section{MATERIALS AND METHODS}

1995 to 1997 field tests. Soybean PIs from maturity group (MG) 0 to III were obtained from the USDA Soybean Germplasm Collection in Urbana for field evaluations in 1995 and 1996. Seed harvested from the 1996 trials were used as a seed source for the 1997 trials. A total of 13 environments were used to evaluate 5,565 PIs for disease incidence and severity in single-row, nonreplicated field plots from 1995 to 1997 by 10 institutions and companies (Table 1). At most locations, these plots were approximately $1 \mathrm{~m}$ long

Table 3. Mean Sclerotinia stem rot ratings for the field and excised leaf inoculations for the maturity group 0 soybean plant introductions and check culti$\operatorname{vars}^{\mathrm{a}}$

\begin{tabular}{|c|c|c|c|c|c|c|c|}
\hline \multirow[b]{3}{*}{ Entry $^{d}$} & \multicolumn{6}{|c|}{ DSI $^{\mathbf{b}}$} & \multirow{3}{*}{$\begin{array}{c}\text { ELI }\left(\mathrm{cm}^{2}\right)^{\mathrm{c}} \\
1998-2000 \\
\text { Lincoln }\end{array}$} \\
\hline & \multicolumn{2}{|c|}{1998} & \multicolumn{2}{|c|}{1999} & \multirow{2}{*}{$\begin{array}{c}2000 \\
\text { Fargo }\end{array}$} & \multirow[b]{2}{*}{ Mean $^{\mathrm{e}}$} & \\
\hline & Elora & Ottawa & Fargo & Ottawa & & & \\
\hline PI 132.207 & 0 & 0 & $\ldots$ & 0 & 0 & 0 & $\ldots$ \\
\hline PI 243.547 & $\ldots$ & 2 & 6 & 8 & 1 & 4 & $5.5 \pm 0.5$ \\
\hline PI 567.157A & 2 & 0 & 26 & 2 & 1 & 6 & $5.7 \pm 0.5$ \\
\hline PI 361.059B & 1 & 0 & 27 & 1 & 4 & 6 & $5.2 \pm 0.5$ \\
\hline PI 417.449 & 3 & 7 & 31 & 2 & 1 & 9 & $6.4 \pm 0.5$ \\
\hline PI 437.527 & 0 & 1 & 41 & 3 & 0 & 9 & $5.0 \pm 0.5$ \\
\hline PI 291.319B & 6 & 0 & 33 & 5 & 1 & 9 & $5.7 \pm 0.5$ \\
\hline PI 437.764 & 1 & 0 & 46 & 3 & 1 & 10 & $5.3 \pm 0.5$ \\
\hline PI 189.899 & 6 & 1 & 44 & 1 & 0 & 10 & $4.9 \pm 0.5$ \\
\hline PI 417.507 & 0 & 0 & 43 & 3 & 6 & 10 & $5.4 \pm 0.5$ \\
\hline PI 417.533 & 1 & 2 & 44 & 11 & 0 & 11 & $6.8 \pm 0.5$ \\
\hline PI 578.501 & 3 & 3 & 36 & 20 & 0 & 12 & $5.1 \pm 0.5$ \\
\hline PI 89.001 & 16 & 2 & 32 & 10 & 3 & 12 & $5.2 \pm 0.5$ \\
\hline Traill (R) & 2 & 0 & 61 & 2 & 0 & 13 & $4.7 \pm 0.5$ \\
\hline PI 437.072 & 8 & 4 & 41 & 12 & 1 & 13 & $5.2 \pm 0.5$ \\
\hline PI 548.404 & 2 & 1 & 19 & 39 & $\ldots$ & 16 & $\ldots$ \\
\hline McCall (R) & 2 & 2 & 67 & 10 & 0 & 16 & $5.3 \pm 0.5$ \\
\hline PI 548.539 & 3 & 1 & 26 & 30 & $\ldots$ & 16 & $6.0 \pm 0.5$ \\
\hline MN 0301 (S) & 8 & 10 & 55 & 9 & 3 & 17 & $6.3 \pm 0.5$ \\
\hline PI 438.267 & 0 & 4 & 50 & 2 & $\ldots$ & 18 & $\ldots$ \\
\hline PI 548.354 & 1 & 0 & 54 & 1 & $\ldots$ & 18 & $\ldots$ \\
\hline Pioneer 9071 (S) & 8 & 13 & 70 & 5 & 4 & 20 & $6.1 \pm 0.5$ \\
\hline PI 189.861 & 7 & 1 & 56 & 3 & $\ldots$ & 21 & $\ldots$ \\
\hline PI 153.259 & 0 & 2 & 61 & 1 & $\ldots$ & 21 & $\ldots$ \\
\hline PI 232.996 & 2 & 2 & 40 & 43 & $\ldots$ & 24 & $\ldots$ \\
\hline Mean & 3 & 3 & 44 & 10 & 2 & 14 & 5.6 \\
\hline $\operatorname{LSD}^{\mathrm{f}}$ & $\mathrm{ns}$ & 7 & 16 & 25 & $\mathrm{~ns}$ & 12 & $\ldots$ \\
\hline
\end{tabular}

a $\ldots=$ entry not evaluated in test.

${ }^{\mathrm{b}}$ DSI $=$ disease severity index that ranged from $0=$ all healthy plants with no disease to $100=$ all plants killed by disease. The DSI means are based on the disease ratings of 30 plants in two replications of plots in Elora and Ottawa, three replications in Fargo in 1999, and four replications in Fargo in 2000.

${ }^{c}$ ELI = excised leaf inoculation. Lesion area measured in square centimeters and each value represents the mean of four replications with one leaf tested in each replication.

${ }^{\mathrm{d}} \mathrm{R}=$ resistant check cultivar and $\mathrm{S}=$ susceptible check cultivar.

e Across-environment mean.

${ }^{\mathrm{f}} \mathrm{LSD}=$ least significant difference for comparing the means of individual lines at $P=0.05$; ns $=$ not significant. 
with a $0.76-\mathrm{m}$ row spacing. Estimates of both disease incidence and severity were taken on each plot. Disease incidence ratings were taken using a 0 -to- 9 scale with 0 $=0$ to $9 \%$ and $9=90$ to $100 \%$ incidence. Disease severities were rated on a 1-to-5 scale with $1=81$ to $100 \%$ of normal seed fill and $5=0$ to $20 \%$ of normal seed fill. Tests were conducted in fields previously known to have the disease and no additional inoculum was applied. Some locations were irrigated. All available MG I to III PIs were evaluated in 1995, and PIs having Sclerotinia stem rot incidence and severity ratings equal to or greater than S19-90 in environments where the disease was present were reevaluated in 1996. This process was repeated in 1997 to identify PIs for the 1998-2000 tests. Not all MG 0 PIs were evaluated in 1995 because of limitations in seed supply and field resources (Table 1). The MG 0 PIs were split into two groups, with some evaluated in 1995 and the remainder evaluated in 1996. Like the MG I to III tests, PIs with resistance equal to or greater than S19-90 were selected and reevaluated in 1997.
Of 3,153 MG IV PIs in the USDA Soybean Germplasm Collection in 1996, 955 were evaluated in the greenhouse from 1996 to 1997 for Sclerotinia stem rot resistance. This includes the 850 MG IV PIs that range from PI 506.478 to PI 592.953, plus an additional 105 diverse MG IV PIs. The greenhouse testing was done using the mycelial plug inoculation method described by Kim et al (19). With this method, plants were inoculated at the V1 to V2 growth stage (10) by placing a single plug mycelial side down on a cotyledon approximately $2 \mathrm{~mm}$ from the stem of each seedling. The mycelial plugs were $3 \mathrm{~mm}$ in diameter and were cut from the margins of an S. sclerotiorum colony growing on potato-dextrose agar (PDA). The seedlings either were hand-misted with water and covered with plastic domes or placed in a misting chamber. Four days after inoculation, plants were rated daily for survival. PIs with a survival rate equal to or greater than S19-90 were selected and retested. The selected PIs were tested in at least two replicates and each experimental unit included at least five plants.
1998 to 2000 field tests. The MG 0 to III PIs selected from 1997 tests were evaluated in eight environments by six institutions (Table 1). Field tests were arranged in randomized complete block designs with two to four replicates at each location (Table 2). The MG IV PIs selected from greenhouse tests in 1997 were evaluated in the field in Urbana in 1999 and 2000. The reaction level of each PI and check cultivar to $S$. sclerotiorum was estimated by a disease severity index (DSI; 15). The DSI ratings were taken at the R7 growth stage, defined as when pods were yellow and $50 \%$ of the leaves were yellow (10). The DSI was determined by rating the disease severity of 30 randomly selected plants in the center rows of plots on a scale of 0 to 3 , where $0=$ no symptoms, $1=$ lesions only found on lateral branches, $2=$ small lesions on main stem not affecting pod fill, and $3=$ lesions on main stem resulting in plant death and poor pod fill. The DSI for each plot was calculated by the formula $D S I=100 \times(\Sigma r / 3 n)$, in which $r$ is the rating of each plant and $n$ is the number of plants rated. This formula stan-

Table 4. Mean Sclerotinia stem rot ratings for the field and excised leaf and petiole inoculations for the maturity group I soybean plant introductions and check cultivars $^{\mathrm{a}}$

\begin{tabular}{|c|c|c|c|c|c|c|c|c|c|c|c|c|}
\hline \multirow[b]{3}{*}{ Entry $^{e}$} & \multicolumn{10}{|c|}{ DSI $^{\mathbf{b}}$} & \multirow{3}{*}{$\frac{\frac{E L I}{\left(\mathrm{~cm}^{2}\right)^{\mathrm{c}}}}{\frac{1998-2000}{\text { Lincoln }}}$} & \multirow{3}{*}{$\begin{array}{c}\text { PIT RI }^{\text {d }} \\
1999 \\
\text { Madison }\end{array}$} \\
\hline & \multicolumn{5}{|c|}{1998} & \multicolumn{2}{|c|}{1999} & \multicolumn{2}{|c|}{2000} & \multirow[b]{2}{*}{ Mean $^{f}$} & & \\
\hline & Elora & Madison & Ottawa & Staples & Urbana & Ottawa & Urbana & Harrow & Urbana & & & \\
\hline PI 391.589B & 8 & 1 & 10 & 2 & 11 & $\ldots$ & 6 & 2 & 5 & 5 & $5.4 \pm 0.4$ & $\ldots$ \\
\hline PI 548.407 & 7 & 3 & 16 & 0 & 16 & 0 & 1 & $\ldots$ & $\ldots$ & 6 & $\ldots$ & $\ldots$ \\
\hline PI 548.312 & 3 & 18 & 11 & 2 & 8 & 1 & 1 & 8 & 1 & 6 & $6.4 \pm 0.4$ & 1.7 \\
\hline PI 561.367 & 2 & 4 & 15 & 0 & 14 & 1 & 7 & 1 & 9 & 6 & $5.3 \pm 0.5$ & 2.4 \\
\hline PI 561.353 & 4 & 0 & 18 & 3 & 16 & 0 & 4 & 0 & 7 & 6 & $6.5 \pm 0.4$ & 2.0 \\
\hline PI 153.282 & 1 & 6 & 15 & 0 & 14 & 3 & 4 & 10 & 2 & 6 & $6.5 \pm 0.5$ & 1.9 \\
\hline PI 427.143 & 8 & 1 & 7 & 0 & 7 & 1 & 1 & 36 & 1 & 7 & $6.5 \pm 0.4$ & 1.8 \\
\hline FC 30.233 & 0 & 6 & 15 & 3 & 6 & 12 & 6 & 12 & 7 & 7 & $\ldots$ & 1.6 \\
\hline PI 189.919 & 0 & 3 & 44 & 0 & 2 & 1 & 2 & 9 & 5 & 7 & $7.3 \pm 0.5$ & 1.2 \\
\hline PI 416.805 & 5 & 2 & 36 & 0 & 20 & 1 & 4 & 7 & 5 & 9 & $6.5 \pm 0.5$ & 1.7 \\
\hline PI 549.066 & - & 1 & 31 & 0 & 11 & 4 & 5 & 26 & 3 & 10 & $6.6 \pm 0.4$ & 1.4 \\
\hline PI 416.776 & 4 & 2 & 27 & 0 & 22 & 2 & 8 & 23 & 3 & 10 & $5.7 \pm 0.5$ & 1.6 \\
\hline Syngenta S19-90 (R) & 5 & 2 & 7 & 3 & 29 & 0 & 23 & 1 & 23 & 10 & $5.2 \pm 0.3$ & 1.4 \\
\hline PI 189.896 & 8 & 26 & 24 & 5 & 15 & 1 & 2 & 5 & 8 & 10 & $6.9 \pm 0.5$ & 1.5 \\
\hline PI 561.284 & 2 & 14 & 31 & 1 & 15 & 1 & 22 & 2 & 11 & 11 & $5.8 \pm 0.5$ & 1.3 \\
\hline PI 153.316 & 1 & 3 & 34 & 1 & 17 & 5 & 7 & 25 & 9 & 11 & $\ldots$ & 1.3 \\
\hline PI 91.733 & 8 & 12 & 26 & 2 & 6 & 0 & 2 & 41 & 6 & 11 & $5.8 \pm 0.4$ & 1.6 \\
\hline PI 561.345 & 4 & 13 & 22 & 26 & 8 & 7 & 5 & $\ldots$ & $\ldots$ & 13 & $\ldots$ & $\ldots$ \\
\hline PI 81.775 & 2 & 8 & 44 & 1 & 31 & 3 & 12 & 14 & 13 & 14 & $5.5 \pm 0.4$ & 1.6 \\
\hline Pioneer 9163 (R) & 12 & 9 & 15 & 12 & 41 & 0 & 20 & 12 & 23 & 16 & $6.2 \pm 0.3$ & 1.3 \\
\hline PI 561.331 & 3 & 14 & 22 & 5 & 16 & 12 & 5 & 65 & 19 & 18 & $6.3 \pm 0.4$ & 1.7 \\
\hline PI 504.502 & - & 29 & 89 & 0 & 3 & 0 & 3 & 20 & 1 & 18 & $5.0 \pm 0.4$ & $\ldots$ \\
\hline PI 548.380 & 3 & 18 & 35 & 6 & 27 & 7 & 21 & 43 & 10 & 19 & $6.1 \pm 0.4$ & 1.5 \\
\hline PI 184.042 & 11 & 10 & 40 & 15 & 32 & 9 & 22 & $\ldots$ & $\ldots$ & 19 & $\ldots$ & $\ldots$ \\
\hline Asgrow A2506 (R) & 2 & 8 & 38 & 5 & 39 & 5 & 26 & 12 & 36 & 19 & $6.4 \pm 0.3$ & 1.2 \\
\hline BSR $101(\mathrm{~S})$ & 22 & 8 & 25 & 14 & 55 & 2 & 21 & 26 & 34 & 23 & $6.5 \pm 0.5$ & 1.3 \\
\hline Conrad 94 (S) & 40 & 29 & 38 & 6 & 44 & 10 & 40 & 38 & 56 & 33 & $6.9 \pm 0.4$ & 1.1 \\
\hline Mean & 7 & 10 & 27 & 4 & 19 & 3 & 10 & 18 & 13 & 11 & 6.1 & 1.5 \\
\hline LSDg & $\mathrm{ns}$ & 16 & 13 & 12 & 23 & ns & 16 & 23 & 13 & 9 & $\ldots$ & 0.5 \\
\hline
\end{tabular}

a $\ldots=$ entry not evaluated in test.

${ }^{\mathrm{b}}$ DSI $=$ disease severity index that ranged from $0=$ all healthy plants with no disease to $100=$ all plants killed by disease. The DSI means are based on the disease ratings of 30 plants in two replications of plots in Elora, Ottawa, and Urbana, and three replications in Madison, Staples, and Harrow.

${ }^{\mathrm{c}}$ ELI $=$ excised leaf inoculation. Lesion area measured in square centimeters and each value represents the mean of four replications with one leaf tested in each replication.

${ }^{\mathrm{d}}$ PIT $=$ petiole inoculation technique calculated by a resistance index $(\mathrm{RI})$ ranging from $1=$ most susceptible to $5=$ most resistant. Each value represents the mean of four replications across two experiments with each experimental unit averaging 12 inoculated plants.

${ }^{\mathrm{e}} \mathrm{R}=$ resistant check cultivar and $\mathrm{S}=$ susceptible check cultivar.

${ }^{\mathrm{f}}$ Across-environment mean.

${ }^{\mathrm{g}} \mathrm{LSD}=$ least significant difference for comparing the means of individual lines at $P=0.05$; ns $=$ not significant. 
dardizes the ratings so they range from 0 , when all rated plants lacked symptoms, to a maximum of 100 , when all rated plants were dead.

The partially resistant check cultivars included in the field evaluations were A2506 and S19-90 for the MG I to IV tests, 'McCall' and 'Traill' for the MG 0 test, Pioneer Brand 9163 (P9163) for the MG I and II tests, and Pioneer Brand 9305 (P9305) for the MG III and IV tests (Tables 3 to 7). The susceptible check cultivars were $\mathrm{MN} 0301$ and Pioneer Brand 9071 (P9071) in the MG 0 test, BSR 101 for the MG I test, Conrad 94 for the MG I and II tests, Resnik in the MG II and III tests, and Williams 82 in the MG III and IV tests (Tables 3 to 7).

The plot sizes varied among locations, with some irrigated by overhead sprinkling or misting (Table 2). Irrigation was applied from the R1 growth stage, defined as when $50 \%$ of the plants in a plot had one open flower at any node (10) to when the plots were evaluated for DSI. One of three methods was used to provide an inoculum source in each environment (Table 2). Plots were located in fields infested with sclerotia generated by epidemics in previous crops, by spreading of sclerotia onto the soil surface, or by spreading ground grain colonized by $S$. sclerotiorum on the leaves and stems. The sclerotia inoculation technique utilized sclerotia separated from screenings of harvested common beans. Prior to planting, the sclerotia were evenly spread over the field and incorporated into the top 2 to $3 \mathrm{~cm}$ of the soil. The ground grain inoculation technique utilized grain such as sorghum, wheat, or oat that was colonized with $S$. sclerotiorum mycelium. The grain-based inoculum was dried, ground, and spread by hand into the top of the soybean canopy of each plot at the R1 growth stage.

Agronomic data recorded on each plot of the MG I to III tests at Urbana were R1 date, percent canopy closure at the $\mathrm{R} 1$ date and at each inoculation date; R8 date, defined as when $95 \%$ of the pods were mature (10); plant lodging at the second inoculation and the R8 date; plant height; and seed yield. Percent canopy closure was estimated as the percentage of the plot land area that was covered by at least one layer of leaves. Plant lodging was recorded using a score of $1=$ all plants erect to $5=$ all plants prostrate. Plant height was measured as centimeters from the ground to the top node of an average-sized plant, and seed yield was calculated to a $13 \%$ moisture basis. The first ground grain inoculation occurred when $50 \%$ of all plots were at least at the R1 growth stage, and a second inoculation occurred 2 to 3 weeks later if the leaves and stems of susceptible checks were not infected with $S$. sclerotiorum from the first inoculation.

1998 to 2000 greenhouse and laboratory testing. The MG 0 to III PIs selected from 1997 field tests and MG IV PIs selected from 1998 field tests, plus check cultivars, were evaluated for Sclerotinia stem rot resistance with the excised leaf inoculation technique in the laboratory at the University of Nebraska-Lincoln during 1998 to 2000. All MG 0 to III PIs were

Table 6. Mean Sclerotinia stem rot ratings for the field and excised leaf inoculations for the maturity group III soybean plant introductions and check cultivars

\begin{tabular}{|c|c|c|c|c|c|}
\hline \multirow[b]{3}{*}{ Entry ${ }^{c}$} & \multicolumn{4}{|c|}{ DSI $^{\mathbf{a}}$} & \multirow{3}{*}{$\begin{array}{c}\text { ELI }^{b} \\
\text { Lincoln } \\
\text { 1999-2000 }\end{array}$} \\
\hline & \multicolumn{3}{|c|}{ Urbana } & \multirow[b]{2}{*}{ Across-year mean } & \\
\hline & 1998 & 1999 & 2000 & & \\
\hline PI 229.324 & 3 & 7 & 26 & 12 & $4.7 \pm 0.5$ \\
\hline PI 417.201 & 7 & 10 & 24 & 14 & $5.3 \pm 0.5$ \\
\hline PI 196.157 & 0 & 19 & 29 & 16 & $5.8 \pm 0.5$ \\
\hline PI 398.637 & 7 & 24 & 21 & 17 & $4.7 \pm 0.5$ \\
\hline PI 404.180 & 1 & 8 & 44 & 18 & $4.8 \pm 0.5$ \\
\hline Pioneer 9305 (R) & 10 & 29 & 28 & 22 & $7.2 \pm 0.4$ \\
\hline PI 423.818 & 13 & 12 & 46 & 24 & $5.1 \pm 0.5$ \\
\hline Asgrow A2506 (R) & 27 & 26 & 41 & 31 & $6.4 \pm 0.3$ \\
\hline Syngenta S19-90 (R) & 31 & 22 & 46 & 33 & $5.1 \pm 0.3$ \\
\hline Williams $82(\mathrm{~S})$ & 35 & 36 & 59 & 43 & $6.6 \pm 0.4$ \\
\hline Resnik (S) & 55 & 37 & 54 & 49 & $6.8 \pm 0.3$ \\
\hline Mean & 17 & 21 & 38 & 25 & 5.6 \\
\hline $\mathrm{LSD}^{\mathrm{d}}$ & 19 & 17 & 19 & 14 & $\ldots$ \\
\hline
\end{tabular}

${ }^{a}$ DSI $=$ disease severity index that ranged from $0=$ all healthy plants with no disease to $100=$ all plants killed by disease. The DSI means are based on the disease ratings of 30 plants in two replications of plots each year in Urbana.

${ }^{\mathrm{b}}$ ELI $=$ excised leaf inoculation. Lesion area measured in square centimeters and each value represents the mean of four replications with one leaf tested in each replication.

${ }^{\mathrm{c}} \mathrm{R}=$ resistant check cultivar and $\mathrm{S}=$ susceptible check cultivar.

${ }^{\mathrm{d}} \mathrm{LSD}=$ least significant difference for comparing the means of individual lines at $P=0.05$.

Table 5. Mean Sclerotinia stem rot ratings for the field and excised leaf and petiole inoculations for the maturity group II soybean plant introductions and check cultivars $^{\mathrm{a}}$

\begin{tabular}{|c|c|c|c|c|c|c|c|c|c|}
\hline \multirow[b]{3}{*}{ Entry ${ }^{\mathrm{e}}$} & \multicolumn{7}{|c|}{ DSI $^{b}$} & \multirow{3}{*}{$\begin{array}{c}\text { ELIc } \\
1998-2000 \\
\text { Lincoln }\end{array}$} & \multirow{3}{*}{$\begin{array}{c}\text { PIT RI }^{\mathrm{d}} \\
1999 \\
\text { Madison }\end{array}$} \\
\hline & \multicolumn{3}{|c|}{1998} & 1999 & \multicolumn{2}{|c|}{2000} & \multirow[b]{2}{*}{ Mean $^{f}$} & & \\
\hline & Elora & Madison & Urbana & Urbana & Urbana & Harrow & & & \\
\hline PI 507.352 & 3 & 1 & 6 & 1 & 4 & 6 & 3 & $8.0 \pm 0.5$ & $\ldots$ \\
\hline PI 507.353 & 4 & 0 & 4 & 1 & 5 & 9 & 4 & $6.2 \pm 0.5$ & 1.9 \\
\hline PI 358.318A & 0 & 3 & 3 & 4 & 31 & 15 & 10 & $6.5 \pm 0.4$ & 1.7 \\
\hline Pioneer 9163 (R) & 12 & 9 & 34 & 15 & 12 & 9 & 15 & $6.2 \pm 0.3$ & 1.6 \\
\hline PI 189.931 & 0 & 6 & 21 & 30 & 32 & 11 & 17 & $6.5 \pm 0.5$ & 1.7 \\
\hline Syngenta S19-90 (R) & 5 & 2 & 29 & 28 & 43 & 3 & 19 & $5.1 \pm 0.3$ & 1.8 \\
\hline Asgrow A2506 (R) & 2 & 8 & 23 & 35 & 38 & 16 & 20 & $6.4 \pm 0.3$ & 1.6 \\
\hline Resnik (S) & 10 & $\ldots$ & 52 & 35 & 58 & 39 & 39 & $6.8 \pm 0.3$ & 1.3 \\
\hline Conrad $94(\mathrm{~S})$ & 40 & 29 & 35 & 30 & 44 & 56 & 39 & $6.9 \pm 0.4$ & 1.5 \\
\hline Mean & 8 & 9 & 23 & 20 & 30 & 20 & 17 & 6.5 & 1.6 \\
\hline $\mathrm{LSD}^{\mathrm{g}}$ & ns & 15 & 14 & ns & 21 & 21 & 12 & $\ldots$ & 0.4 \\
\hline
\end{tabular}

a $\ldots=$ entry not evaluated in test.

${ }^{\mathrm{b}}$ DSI $=$ disease severity index that ranged from $0=$ all healthy plants with no disease to $100=$ all plants diseased and dead. The DSI means are based on the disease ratings of 30 plants in two replications of plots in Elora and Urbana, and three replications in Madison and Harrow.

${ }^{c}$ ELI = excised leaf inoculation. Lesion area measured in square centimeters and each value represents the mean of four replications with one leaf tested in each replication.

${ }^{\mathrm{d}} \mathrm{PIT}=$ petiole inoculation technique calculated by a resistance index $(\mathrm{RI})$ ranging from $1=$ most susceptible to $5=$ most resistant. Each value represents the mean of four replications across two experiments with each experimental unit averaging 12 inoculated plants.

e $\mathrm{R}=$ resistant check cultivar and $\mathrm{S}=$ susceptible check cultivar.

f Across-environment mean.

g LSD = least significant difference for comparing the means of individual lines at $P=0.05$; ns $=$ not significant. 
evaluated together in each year from 1998 to 2000, and MG IV PIs were evaluated in two tests in 1999 and 2000. The excised leaf inoculation procedure was described in detail by Kim et al. (19). Twenty-eightday-old plants were sampled by collecting four replicates of leaves. Each replicate was one leaf, which was the youngest fully expanded trifoliolate leaf from a plant. The leaf was detached at the juncture of the petiole and main stem, and the petioles were placed in orchid tubes containing water. Each leaf was placed on a glass petri plate, and four petri plates were placed in an aluminum roasting pan lined with a moist paper towel. An 8-mm plug of $S$. sclerotiorum, taken from the advancing colony margin of a $37-$ to 48 -h culture grown on PDA, was placed between the veins of the middle leaflet of each triloliolate. The pans were covered tightly with plastic wrap to maintain a high humidity level and were kept at a constant temperature of $22 \pm 1^{\circ} \mathrm{C}$. After $48 \mathrm{~h}$ of incubation, the length and width of the each lesion was measured, and the lesion area of an ellipse in square centimeters was calculated.

The MG I and II PIs selected from 1997 field tests, plus check cultivars, were evaluated for Sclerotinia stem rot resistance with a petiole inoculation technique in greenhouses and growth chambers at the University of Wisconsin-Madison during scribed in detail by Del Rio et al. (8). The PIs were planted in 96-cell plastic inserts 1999. The inoculation procedure was de-

(T. O. Plastics, Clearwater, MN) filled with Redi-earth potting mixture (Scotts, Marysville, $\mathrm{OH}$ ). The greenhouse was set at $22^{\circ} \mathrm{C}$ during a 14-h photoperiod and $18^{\circ} \mathrm{C}$ at night, and the growth chambers were set at $22^{\circ} \mathrm{C}$ during a 12 -h photoperiod and $20^{\circ} \mathrm{C}$ at night. When the second trifoliolate leaf was fully open, the petiole of the first fully expanded trifoliolate leaf was cut off 2.5 $\mathrm{cm}$ from the stem and inoculated. The inoculum was produced by seeding mycelium of Arlington 99, a highly virulent $S$. sclerotiorum isolate, in petri dishes containing an 8-mm-thick layer of PDA. The fungus was incubated for $48 \mathrm{~h}$ at $21^{\circ} \mathrm{C}$ and $12 \mathrm{~h}$ of light daily. Plastic drinking straws (6 $\mathrm{mm}$ in diameter) were cut into pieces of $2.5 \mathrm{~cm}$ each. Pieces were folded and stapled at one end, leaving a 2-cm-long straw that was used to cut a plug from the leading edge of the colony. The straw pieces were pushed against the agar until they hit the bottom of the dish. Then, with a lateral move, they were lifted, bringing the agar plug inside. Loaded straws were pushed against the petiole tip by pressing the straw between the mycelial plug and the stapled end of the straw. The cut petiole was capped with an inoculum-loaded straw until its tip penetrated the agar and made contact with the mycelium. Wilted plants, with tips bent over or with flaccid leaves, were recorded and removed daily. A resistance index (RI) ranging from 1 to 5 , with $1=$ highly susceptible and 5= highly resistant, was calculated considering only

Table 7. Mean Sclerotinia stem rot ratings for the field and excised leaf inoculations for the maturity group IV soybean plant introductions and check cultivars ${ }^{\mathrm{a}}$

\begin{tabular}{|c|c|c|c|c|}
\hline \multirow[b]{3}{*}{ Entry $^{d}$} & \multicolumn{3}{|c|}{ DSI $^{\mathbf{b}}$} & \multirow{3}{*}{$\begin{array}{c}\text { ELI }^{c} \\
\text { Lincoln } \\
1999-2000\end{array}$} \\
\hline & \multicolumn{2}{|c|}{ Urbana } & \multirow[b]{2}{*}{ Across-year mean } & \\
\hline & 1999 & 2000 & & \\
\hline PI 567.650B & 8 & $\ldots$ & 8 & \\
\hline PI 506.652 & 4 & 18 & 11 & $5.7 \pm 0.5$ \\
\hline PI 506.784 & 12 & 11 & 11 & $5.2 \pm 0.5$ \\
\hline PI 506.654 & 7 & 20 & 13 & $5.6 \pm 0.5$ \\
\hline PI 506.892 & 11 & 20 & 15 & $5.2 \pm 0.5$ \\
\hline PI 506.868 & 12 & 22 & 17 & $5.3 \pm 0.5$ \\
\hline PI 507.222 & 13 & 23 & 18 & $5.5 \pm 0.5$ \\
\hline PI 561.388 & 10 & 30 & 20 & $5.0 \pm 0.5$ \\
\hline PI 594.286 & 5 & 36 & 20 & $6.3 \pm 0.5$ \\
\hline PI 417.245 & 12 & 30 & 21 & $4.1 \pm 0.5$ \\
\hline PI 506.733A & 5 & 37 & 21 & $4.1 \pm 0.5$ \\
\hline PI 506.728 & 8 & 37 & 23 & $5.4 \pm 0.5$ \\
\hline PI 506.519 & 26 & $\ldots$ & 26 & $\ldots$ \\
\hline Pioneer P9305 (R) & 6 & 46 & 26 & $\ldots$ \\
\hline Asgrow A2506 (R) & 16 & 38 & 27 & $\ldots$ \\
\hline PI 594.289 & 30 & $\ldots$ & 30 & $\ldots$ \\
\hline PI 567.721 & 12 & 56 & 34 & $6.1 \pm 0.5$ \\
\hline Syngenta S19-90 (R) & 28 & 42 & 35 & $5.2 \pm 0.5$ \\
\hline Williams $82(\mathrm{~S})$ & 48 & 65 & 57 & $6.5 \pm 0.5$ \\
\hline Mean & 14 & 33 & 23 & 5.4 \\
\hline $\mathrm{LSD}^{\mathrm{e}}$ & 17 & 21 & 13 & $\ldots$ \\
\hline
\end{tabular}

a $\ldots=$ entry not evaluated in test.

${ }^{\mathrm{b}} \mathrm{DSI}=$ disease severity index that ranged from $0=$ all healthy plants with no disease to $100=$ all plants killed by disease. The DSI means are based on the disease ratings of 30 plants in two replications of plots each year in Urbana.

${ }^{\mathrm{c}}$ ELI = excised leaf inoculation. Lesion area measured in square centimeters and each value represents the mean of four replications with one leaf tested in each replication.

${ }^{\mathrm{d}} \mathrm{R}=$ resistant check cultivar and $\mathrm{S}=$ susceptible check cultivar.

${ }^{\mathrm{e}} \mathrm{LSD}=$ least significant difference for comparing the means of individual lines at $P=0.05$. plants with visible disease reactions to avoid rating plants that did not come in contact with the pathogen. The RI was calculated using the formula $\mathrm{RI}=\left(\mathrm{C}_{1}+\left[\mathrm{C}_{2}\right.\right.$ $\left.\times 2]+\left[\mathrm{C}_{3} \times 3\right]+\left[\mathrm{C}_{4} \times 4\right]+\left[\mathrm{C}_{5} \times 5\right]\right) /\left(\mathrm{C}_{1}+\right.$ $\mathrm{C}_{2}+\mathrm{C}_{3}+\mathrm{C}_{4}+\mathrm{C}_{5}$ ), where $\mathrm{C}_{1}$ through $\mathrm{C}_{5}=$ number of wilted plants $4,6,8,10$, and $>10$ days after inoculation, respectively.

Each experiment had four replications and was repeated once. Each experimental unit averaged 12 inoculated plants.

The field and petiole inoculation technique tests were analyzed by the PROC GLM procedure in SAS, and the excised leaf inoculation tests were analyzed by the PROC MIXED procedure in SAS (version 8.1). Environments and replications were analyzed as random effects and genotypes as fixed effects. Least squares means (LSMEANS) were calculated for each entry in all MG tests using the PROC GLM and MIXED procedures in SAS (version 8.1). Least significant differences (LSD) were calculated for the field and petiole inoculation technique tests, and $t$ tests were calculated to compare PIs within each MG with the resistant and susceptible checks. Linear correlations were calculated with PROC CORR in SAS to compare the mean DSI ratings of genotypes with agronomic traits recorded at the Urbana environment for each MG test and with the excised leaf inoculation and petiole inoculation techniques. All significant levels stated in the results and discussions are at the 5\% probability level unless otherwise noted.

\section{RESULTS}

1995 to 1997 field and greenhouse tests. Levels of Sclerotinia stem rot that were sufficient to allow for selection occurred in only some environments during 1995 to 1997 (Table 1). The diseased field sites resulted in the elimination of 5,512 $(99.0 \%)$ PIs from the original 5,565. This included the elimination of $997(97.8 \%)$ MG 0, 1,405 (98.5\%) MG I, 1,662 (99.8\%) MG II, and 1,448 (99.6\%) MG III PIs. Additionally, 835 (98.3\%) of the 840 MG IV PIs were eliminated based on the greenhouse evaluations.

1998 to 2000 field tests. Only those environments where genotypes have mean DSI levels of at least 5 were included in the tables and data analysis (Tables 3 to 7). In the across-environment analysis for each maturity group, genotypes differed significantly for DSI, and there was a significant genotype-environment interaction for DSI. In the MG 0 test, the mean DSI for environments ranged from 2 in Fargo in 2000 to 44 in Fargo in 1999 (Table 3). The genotypic variance was not significant among the 25 MG 0 PIs and checks evaluated at Elora in 1998 and Fargo in 2000, although it was significant at the other environments. Only PI 132.207 had significantly less disease than Traill, the most resistant check cultivar across environments. No PIs had consistently less disease than the most 
resistant checks at all environments, although 21 PIs had a resistance level not significantly different from the resistant checks across environments.
There was significant genotypic variation among the 27 MG I PIs and check cultivars in all environments except for Elora in 1998 and Ottawa in 1999 (Table
4). No PI had significantly less disease across environments than S19-90, the most resistant check. In each of the 3 years at Urbana, PIs 189.919 and 504.502 had sig-

Table 8. Mean Sclerotinia stem rot ratings for maturity group I soybean plant introductions and check cultivars across all diseased environments and only at Urbana, IL and agronomic ratings from Urbana during 1998 to 2000

\begin{tabular}{|c|c|c|c|c|c|c|c|c|c|c|c|}
\hline \multirow[b]{2}{*}{ Entry ${ }^{c}$} & \multicolumn{2}{|c|}{ DSI $^{\mathbf{a}}$} & \multicolumn{9}{|c|}{ Agronomic traits ${ }^{b}$} \\
\hline & $\begin{array}{c}\text { Across } \\
\text { all }\end{array}$ & $\begin{array}{c}\text { Urbana } \\
\text { only }\end{array}$ & $\begin{array}{c}\text { R1 } \\
\text { date }\end{array}$ & $\begin{array}{c}\text { R1Can } \\
(\%)\end{array}$ & $\underset{(\%)}{\text { Can1 }}$ & $\begin{array}{c}\text { Can2 } \\
(\%)\end{array}$ & $\begin{array}{c}\text { LodIno } \\
\text { (score) }\end{array}$ & $\begin{array}{c}\text { Maturity } \\
\text { date }\end{array}$ & $\begin{array}{c}\text { Lod } \\
\text { (score) }\end{array}$ & $\begin{array}{c}\text { Height } \\
\text { (cm) }\end{array}$ & $\begin{array}{c}\text { Yield } \\
\text { (kg/ha) }\end{array}$ \\
\hline PI 391.589B & 5 & 7 & $1 \mathrm{Jul}$ & 85 & 98 & 99 & 1.1 & $8 \mathrm{Sep}$ & 1.1 & 63 & 2,313 \\
\hline PI 548.407 & 6 & 8 & $5 \mathrm{Jul}$ & 80 & 85 & 100 & 1.4 & 4 Sep & 1.3 & 44 & 1,494 \\
\hline PI 548.312 & 6 & 3 & 30 Jun & 73 & 91 & 90 & 2.1 & 2 Sep & 2.3 & 65 & 2,261 \\
\hline PI 561.367 & 6 & 10 & 29 Jun & 71 & 97 & 100 & 1.1 & 7 Sep & 1.0 & 57 & 2,847 \\
\hline PI 561.353 & 6 & 9 & 29 Jun & 75 & 97 & 100 & 1.3 & $7 \mathrm{Sep}$ & 1.0 & 56 & 2,818 \\
\hline PI 153.282 & 6 & 7 & 29 Jun & 73 & 98 & 96 & 1.8 & 2 Sep & 2.0 & 73 & 2,353 \\
\hline PI 427.143 & 7 & 3 & $2 \mathrm{Jul}$ & 65 & 88 & 96 & 1.0 & 4 Sep & 1.0 & 43 & 1,593 \\
\hline FC 30.233 & 7 & 6 & 28 Jun & 80 & 99 & 100 & 1.3 & $1 \mathrm{Sep}$ & 1.8 & 68 & 2,713 \\
\hline PI 189.919 & 7 & 3 & $1 \mathrm{Jul}$ & 83 & 97 & 95 & 2.6 & $4 \mathrm{Sep}$ & 2.9 & 66 & 1,749 \\
\hline PI 416.805 & 9 & 9 & $3 \mathrm{Jul}$ & 84 & 98 & 100 & 1.5 & 2 Sep & 1.9 & 57 & 2,028 \\
\hline PI 549.066 & 10 & 6 & $1 \mathrm{Jul}$ & 78 & 89 & 100 & 1.0 & 7 Sep & 1.0 & 34 & 1,565 \\
\hline PI 416.776 & 10 & 11 & $5 \mathrm{Jul}$ & 81 & 91 & 96 & 1.3 & 10 Sep & 1.3 & 62 & 1,847 \\
\hline Syngenta S19-90 (R) & 10 & 25 & $2 \mathrm{Jul}$ & 88 & 99 & 100 & 1.1 & 14 Sep & 1.2 & 87 & 3,243 \\
\hline PI 189.896 & 10 & 8 & $2 \mathrm{Jul}$ & 63 & 91 & 94 & 1.5 & 7 Sep & 1.7 & 49 & 1,737 \\
\hline PI 561.284 & 11 & 16 & 28 Jun & 64 & 99 & 100 & 1.3 & 7 Sep & 1.8 & 72 & 2,745 \\
\hline PI 153.316 & 11 & 11 & 30 Jun & 83 & 100 & 100 & 1.4 & 4 Sep & 1.7 & 69 & 2,711 \\
\hline PI 91.733 & 11 & 4 & 29 Jun & 75 & 97 & 98 & 1.3 & 5 Sep & 1.5 & 56 & 2,282 \\
\hline PI 561.345 & 13 & 6 & 7 Jul & 89 & 94 & 99 & 1.2 & 9 Sep & 1.4 & 41 & 2,214 \\
\hline PI 81.775 & 14 & 19 & 29 Jun & 77 & 99 & 99 & 1.5 & 1 Sep & 2.1 & 86 & 2,241 \\
\hline Pioneer 9163 (R) & 16 & 28 & 30 Jun & 79 & 99 & 100 & 1.1 & 12 Sep & 1.5 & 80 & 3,220 \\
\hline PI 504.502 & 18 & 2 & 29 Jun & 68 & 92 & 98 & 1.2 & 2 Sep & 1.0 & 45 & 1,500 \\
\hline PI 561.331 & 18 & 13 & $5 \mathrm{Jul}$ & 76 & 94 & 96 & 1.6 & 8 Sep & 2.0 & 78 & 2,652 \\
\hline Asgrow A2506 (R) & 19 & 34 & $2 \mathrm{Jul}$ & 81 & 98 & 100 & 1.0 & 19 Sep & 1.2 & 86 & 2,952 \\
\hline PI 184.042 & 19 & 27 & $2 \mathrm{Jul}$ & 78 & 99 & 98 & 2.5 & 3 Sep & 2.4 & 70 & 2,200 \\
\hline PI 548.380 & 19 & 19 & 28 Jun & 78 & 99 & 98 & 2.8 & 30 Aug & 2.8 & 81 & 2,157 \\
\hline BSR 101(S) & 23 & 37 & 3 Jul & 81 & 99 & 100 & 1.0 & 16 Sep & 1.9 & 84 & 3,022 \\
\hline Conrad 94(S) & 33 & 47 & $2 \mathrm{Jul}$ & 86 & 100 & 100 & 1.1 & 19 Sep & 1.3 & 83 & 2,988 \\
\hline Mean & 11 & 14 & $1 \mathrm{Jul}$ & 77 & 96 & 98 & 1.6 & 7 Sep & 1.6 & 66 & 2,358 \\
\hline $\mathrm{LSD}^{\mathrm{d}}$ & 9 & 10 & 2 & 15 & 7 & 6 & 1.4 & 4 & 0.8 & 9 & 609 \\
\hline
\end{tabular}

${ }^{a}$ DSI $=$ disease severity index that ranged from $0=$ all rated plants not diseased to $100=$ all plants killed by disease. The across-environment mean is over nine environments for a total of 21 replications of data. The Urbana-environment means are across three Urbana environments for a total of six replications of data. In each plot, 30 plants were rated for disease severity.

${ }^{\mathrm{b}} \mathrm{R} 1$ date $=$ flowering date, $\mathrm{R} 1 \mathrm{Can}=$ percent canopy closure over the plot at the R1 date, Can $1=$ percent canopy closure over the plot at the first inoculation, Can $2=$ percent canopy closure over the plot at the second inoculation, LodIno = plant lodging at the second inoculation, Maturity date $=\mathrm{R} 8$ date, Lod = plant lodging at R8, Height = plant height at R8, and Yield = seed yield. The means are across three environments for a total of six replications of data.

${ }^{\mathrm{c}} \mathrm{R}=$ resistant check cultivar and $\mathrm{S}=$ susceptible check cultivar.

${ }^{\mathrm{d}} \mathrm{LSD}=$ least significant difference for comparing the means of individual lines at $P=0.05$.

Table 9. Mean Sclerotinia stem rot ratings for maturity group II soybean plant introductions and check cultivars across all diseased environments and only at Urbana, IL and agronomic ratings from Urbana during 1998 to 2000

\begin{tabular}{|c|c|c|c|c|c|c|c|c|c|c|c|}
\hline \multirow[b]{2}{*}{ Entryc } & \multicolumn{2}{|c|}{ DSI $^{\mathbf{a}}$} & \multicolumn{9}{|c|}{ Agronomic traits $^{b}$} \\
\hline & $\begin{array}{c}\text { Across } \\
\text { all }\end{array}$ & $\begin{array}{c}\text { Urbana } \\
\text { only }\end{array}$ & $\begin{array}{c}\text { R1 } \\
\text { date }\end{array}$ & $\begin{array}{c}\text { R1Can } \\
(\%)\end{array}$ & $\begin{array}{c}\text { Can1 } \\
(\%)\end{array}$ & $\begin{array}{c}\text { Can2 } \\
(\%)\end{array}$ & $\begin{array}{c}\text { LodIno } \\
\text { (score) }\end{array}$ & $\begin{array}{c}\text { Maturity } \\
\text { date }\end{array}$ & $\begin{array}{c}\text { Lod } \\
\text { (score) }\end{array}$ & $\begin{array}{c}\text { Height } \\
\text { (cm) }\end{array}$ & $\begin{array}{c}\text { Yield } \\
\text { (kg/ha) }\end{array}$ \\
\hline PI 507.353 & 3 & 3 & 3 Jul & 83 & 93 & 95 & 1.0 & $10 \mathrm{Sep}$ & 1.1 & 52 & 1,941 \\
\hline PI 507.352 & 4 & 4 & $4 \mathrm{Jul}$ & 76 & 88 & 93 & 1.0 & $10 \mathrm{Sep}$ & 1.0 & 46 & 1,601 \\
\hline PI 358.318A & 10 & 13 & $5 \mathrm{Jul}$ & 78 & 91 & 91 & 1.1 & 14 Sep & 1.0 & 56 & 1,554 \\
\hline Pioneer $9163(\mathrm{R})^{\mathrm{c}}$ & 15 & 20 & 30 Jun & 78 & 98 & 100 & 1.5 & 14 Sep & 2.0 & 81 & 2,910 \\
\hline PI 189.931 & 17 & 27 & $1 \mathrm{Jul}$ & 83 & 98 & 96 & 2.3 & 14 Sep & 2.2 & 68 & 2,298 \\
\hline Syngenta S19-90 (R) & 19 & 34 & $2 \mathrm{Jul}$ & 88 & 98 & 100 & 1.2 & 15 Sep & 1.2 & 81 & 3,338 \\
\hline Asgrow A2506 (R) & 20 & 32 & $1 \mathrm{Jul}$ & 81 & 97 & 100 & 1.4 & 19 Sep & 1.5 & 82 & 3,492 \\
\hline Resnik (S) & 39 & 48 & $4 \mathrm{Jul}$ & 90 & 99 & 100 & 1.2 & 25 Sep & 1.5 & 89 & 2,906 \\
\hline Conrad $94(\mathrm{~S})^{\mathrm{c}}$ & 39 & 36 & $2 \mathrm{Jul}$ & 84 & 98 & 100 & 1.3 & 21 Sep & 1.5 & 81 & 2,958 \\
\hline Mean & 17 & 24 & $2 \mathrm{Jul}$ & 82 & 96 & 97 & 1.3 & $16 \mathrm{Sep}$ & 1.4 & 71 & 2,555 \\
\hline $\operatorname{LSD}^{\mathrm{d}}$ & 12 & 12 & 3 & ns & 6 & 7 & 1.3 & 8 & 0.9 & 17 & 735 \\
\hline
\end{tabular}

${ }^{\text {a }}$ DSI $=$ disease severity index that ranged from $0=$ all rated plants not diseased to $100=$ all plants killed by disease. The across-environment mean is over six environments for a total of 14 replications of data. The Urbana-environment means are across three Urbana environments for a total of six replications of data. In each plot, 30 plants were rated for disease severity.

${ }^{\mathrm{b}} \mathrm{R} 1$ date $=$ flowering date, $\mathrm{R} 1 \mathrm{Can}=$ percent canopy closure over the plot at the R1 date, Can $1=$ percent canopy closure over the plot at the first inoculation, Can 2 = percent canopy closure over the plot at the second inoculation, LodIno = plant lodging at the second inoculation, Maturity date $=$ R8 date, Lod = plant lodging at R8, Height = plant height at R8, and Yield = seed yield. The means are across three environments for a total of six replications of data.

${ }^{c} \mathrm{R}=$ resistant check cultivar and $\mathrm{S}=$ susceptible check cultivar.

${ }^{\mathrm{d}}$ LSD $=$ least significant difference for comparing the means of individual lines at $P=0.05$; ns $=$ not significant. 
nificantly less disease than the resistant checks. The mean DSI of environments for the MG I tests ranged from 3 in Ottawa in 1999 to 27 in Ottawa in 1998.

In the MG II tests, PI 507.352 had significantly less disease across environments than P9163, the most resistant check (Table 5). There was significant genotypic variation at all environments except for Elora in 1998 and Urbana in 1999. The MG III tests had significant genotypic variation at each environment and across environments, and no PI had significantly lower DSI than P9305, the most resistant check in this test (Table 6). PIs 506.562, 506.784, and 567.650B had significantly less disease than the P9305 in the MG IV tests across years in Urbana, and there was significant genotypic variation for each year (Table 7). Across the five MGs, 68 of 6,415 PIs had resistance levels that were not significantly different than the resistant checks (Tables 3 to 7).

1998 to 2000 agronomic tests. Agronomic data collected for the MG I to III tests in Urbana indicated that selected PIs were generally shorter and yielded less than the resistant and susceptible checks. The variability in the MG I tests was low among the entries for R1 date, canopy closure at all three ratings, lodging at the second inoculation, and maturity (Table 8). Most PIs were similar to the checks with a $90 \%$ canopy closure at both inoculations and a lodging score of 1.5 or better at both lodging dates. PIs 153.282 and 561.331 were the most similar to the resistant checks in all the agronomic categories, except PI 561.331 had a later R1 date than A2506 and S19-90, and PI 153.282 matured earlier than P9163. The variability in the MG II tests was low for all agronomic traits tested, except all PIs had lower seed yield and shorter plant heights than the checks (Table 9). PI 189.931 was the most similar to the resistant checks across the agronomic categories, but it lodged the most at both lodging dates.

All PIs in the MG III tests had significantly later R1 dates and lower seed yield than the resistant checks (Table 10). All PIs had similar canopy closures at all dates recorded compared with the checks, but the PIs tended to have more lodging at both lodging dates. PIs 196.157, 398.637, 417.201, and 423.818 were the most similar to the resistant checks, except all flowered later and had less seed yield.

Associations between DSI and agronomic traits for the MG I to III tests at Urbana. The DSI for each MG I to III test had a significant positive correlation with plant height but was not significantly correlated with lodging (Table 11). For the MG I and II tests, the DSI was positively correlated with canopy closure at both inoculations, maturity, and seed yield. The DSI for the MG II tests had significant, positive associations with percent canopy closure at the R1 date, while the DSI for the MG III tests had a significant, negative association with R1 date. Although canopy closure at the second inoculation and seed yield were not significantly associated with DSI for all MGs, the trend was for increased DSI to be associated with greater canopy closure and more seed yield.

Greenhouse and laboratory testing. There were significant genotypic differences for all greenhouse tests except the MG IV excised leaf inoculation test. Al-

Table 10. Mean Sclerotinia stem rot and agronomic ratings for maturity group III soybean plant introductions and check cultivars evaluated at Urbana, IL during 1998 to 2000

\begin{tabular}{|c|c|c|c|c|c|c|c|c|c|c|}
\hline \multirow[b]{2}{*}{ Entry ${ }^{b}$} & \multirow[b]{2}{*}{ DSI $^{c}$} & \multicolumn{9}{|c|}{ Agronomic traits ${ }^{a}$} \\
\hline & & $\begin{array}{c}\text { R1 } \\
\text { date }\end{array}$ & $\begin{array}{c}\text { R1Can } \\
(\%)\end{array}$ & $\underset{(\%)}{\text { Can1 }}$ & $\begin{array}{c}\text { Can2 } \\
(\%)\end{array}$ & $\begin{array}{c}\text { LodIno } \\
\text { (score) }\end{array}$ & $\begin{array}{c}\text { Maturity } \\
\text { date }\end{array}$ & $\begin{array}{c}\text { Lod } \\
\text { (score) }\end{array}$ & $\begin{array}{c}\text { Height } \\
\text { (cm) }\end{array}$ & $\begin{array}{c}\text { Yield } \\
\text { (kg/ha) }\end{array}$ \\
\hline PI 229.324 & 12 & $20 \mathrm{Jul}$ & 91 & 87 & 86 & 2.4 & 29 Sep & 2.3 & 72 & 1,048 \\
\hline PI 417.201 & 14 & $15 \mathrm{Jul}$ & 96 & 94 & 98 & 2.0 & 03 Oct & 2.1 & 67 & 1,437 \\
\hline PI 196.157 & 16 & $18 \mathrm{Jul}$ & 98 & 95 & 94 & 1.2 & 26 Sep & 1.3 & 70 & 1,816 \\
\hline PI 398.637 & 17 & $21 \mathrm{Jul}$ & 99 & 98 & 99 & 2.1 & 03 Oct & 1.8 & 75 & 1,410 \\
\hline PI 404.180 & 18 & $27 \mathrm{Jul}$ & 98 & 92 & 94 & 2.5 & 09 Oct & 4.0 & 68 & 809 \\
\hline Pioneer 9305 (R) & 22 & $02 \mathrm{Jul}$ & 86 & 97 & 99 & 1.3 & $26 \mathrm{Sep}$ & 1.6 & 81 & 3,163 \\
\hline PI 423.818 & 24 & $24 \mathrm{Jul}$ & 100 & 98 & 100 & 1.9 & 04 Oct & 2.1 & 74 & 1,638 \\
\hline Asgrow A2506 (R) & 31 & $02 \mathrm{Jul}$ & 80 & 99 & 100 & 1.0 & 19 Sep & 1.4 & 85 & 3,121 \\
\hline Syngenta S19-90 (R) & 33 & $02 \mathrm{Jul}$ & 88 & 100 & 100 & 1.3 & 16 Sep & 1.3 & 83 & 3,038 \\
\hline Williams $82(\mathrm{~S})$ & 43 & $10 \mathrm{Jul}$ & 99 & 100 & 100 & 1.8 & 07 Oct & 2.5 & 110 & 1,898 \\
\hline Resnik (S) & 49 & $03 \mathrm{Jul}$ & 87 & 98 & 99 & 1.1 & 26 Sep & 1.4 & 92 & 2,500 \\
\hline Mean & 25 & $13 \mathrm{Jul}$ & 93 & 96 & 97 & 1.7 & 29 Sep & 2.0 & 80 & 1,989 \\
\hline $\operatorname{LSD}^{\mathrm{d}}$ & 14 & 5 & 9 & 9 & 13 & 1.3 & 10 & 0.9 & 14 & 938 \\
\hline
\end{tabular}

${ }^{\mathrm{a}} \mathrm{R} 1$ date $=$ flowering date, $\mathrm{R} 1 \mathrm{Can}=$ percent canopy closure over the plot at the R1 date, Can $1=$ percent canopy closure over the plot at the first inoculation, Can $2=$ percent canopy closure over the plot at the second inoculation, LodIno $=$ plant lodging at the second inoculation, Maturity date $=\mathrm{R} 8$ date, Lod = plant lodging at R8, Height $=$ plant height at R8, and Yield $=$ seed yield. The means are across three environments for a total of six replications of data.

${ }^{\mathrm{b}} \mathrm{R}=$ resistant check cultivar and $\mathrm{S}=$ susceptible check cultivar.

${ }^{\mathrm{c}}$ DSI $=$ disease severity index that ranged from $0=$ all rated plants not diseased to $100=$ all plants killed by disease. The DSI means are across three Ur-

bana environments for a total of six replications of data. In each plot, 30 plants were rated for disease severity.

${ }^{\mathrm{d}} \mathrm{LSD}=$ least significant difference for comparing the means of individual lines at $P=0.05$.

Table 11. Correlations between field disease severity index values for Sclerotinia stem rot resistance and agronomic values for soybean plant introductions and check cultivars across years at Urbana, IL for maturity group (MG) I to III tests

\begin{tabular}{|c|c|c|c|c|c|c|c|c|c|}
\hline \multirow[b]{2}{*}{ MG } & \multicolumn{9}{|c|}{ Agronomic traits ${ }^{a}$} \\
\hline & $\begin{array}{c}\text { R1 } \\
\text { date }\end{array}$ & $\begin{array}{c}\text { R1 } \\
\operatorname{Can}(\%)\end{array}$ & $\begin{array}{c}\text { Can1 } \\
(\%)\end{array}$ & $\underset{(\%)}{\operatorname{Can} 2}$ & $\begin{array}{c}\text { LodIno } \\
\text { (score) }\end{array}$ & $\begin{array}{l}\text { Maturity } \\
\text { date }\end{array}$ & $\begin{array}{l}\text { Lodging } \\
\text { (score) }\end{array}$ & $\begin{array}{l}\text { Height } \\
\text { (cm) }\end{array}$ & $\begin{array}{c}\text { Yield } \\
\text { (kg/ha) }\end{array}$ \\
\hline I & 0.08 & 0.35 & $0.53 * *$ & $0.41 *$ & -0.20 & $0.70 * * *$ & 0.02 & $0.71 * * *$ & $0.59 * *$ \\
\hline II & -0.36 & $0.75^{*}$ & $0.85 * *$ & $0.79 * *$ & 0.24 & $0.92 * * *$ & 0.41 & $0.92 * * *$ & $0.78 * *$ \\
\hline III & $-0.64 *$ & -0.33 & $0.67 *$ & 0.58 & -0.53 & -0.24 & -0.26 & $0.88 * * *$ & 0.54 \\
\hline
\end{tabular}

${ }^{\mathrm{a}} \mathrm{R} 1$ date $=$ flowering date, $\mathrm{R} 1 \mathrm{Can}=$ percent canopy closure over the plot at the R1 date, Can1 = percent canopy closure over the plot at the first inoculation, Can $2=$ percent canopy closure over the plot at the second inoculation, LodIno = plant lodging at the second inoculation date, Maturity date $=$ R8 date, Lodging $=$ plant lodging at R8, Height $=$ plant height at R8, and Yield $=$ seed yield. The disease severity index and agronomic values are based on six replications of data across three years for 27 entries in the MG I test, 9 entries in the MG II test, and 11 entries in the MG III test; *, **, and *** = significant at the $0.05,0.01$, and 0.001 probability level, respectively. 
though significant differences were found in the MG 0 to III excised leaf inoculation tests, no PI differed significantly from either the resistant or susceptible checks (Tables 3 to 5). Significant differences were found in the MG I and II tests using the petiole inoculation technique (Tables 4 and 5). In the MG I test, PIs 561.353 and 561.367 had significantly less disease than the most resistant check, S19-90 (Table 4). None of the PIs in the MG II test were significantly more resistant than the any of the resistant checks (Table 5). Ratings from the petiole inoculation technique were negatively $(P<0.01)$ correlated with the DSI ratings in the MG I and II tests, indicating that this method was predictive of field performance (Table 12). The correlation was negative because high DSI ratings indicate low resistance, whereas high ratings with the petiole inoculation technique indicate high resistance. The excised leaf inoculation test was significantly correlated with the DSI ratings only in the MG III test (Table 12).

\section{DISCUSSION}

Through the selection and repeated testing of PIs with low DSI ratings, we have identified PIs with a high level of resistance to Sclerotinia stem rot. There are no known sources of complete resistance to Sclerotinia stem rot in soybean; therefore, this evaluation process was important to provide sources that can be used to improve the resistance level of elite soybean germ plasm.

Mean DSI values of 10 or lower occurred in nine environments for the MG 0 and I tests, but there was significant genotypic variation in five of these tests (Tables 3 and 4). This indicates that environments with a low mean DSI can be used to separate resistant and susceptible genotypes. In future tests, we may be able to utilize environments with low mean DSI values in the evaluation and selection of soybean genotypes with Sclerotinia stem rot resistance.

PIs with shorter plant height, less canopy closure at both inoculations, and earlier maturity dates in the MG I to III tests had less disease severity on average (Table 11). For example, PI 507.352 and PI 507.353 had the lowest DSI values in the MG II test but had only about $60 \%$ of the height of the checks (Table 9). PIs such as these may have low DSI values because of disease escape and not physiological resistance. These agronomic characteristics would allow more airflow through the soybean canopy, resulting in an unfavorable environment for disease development. Other researchers have reported plant height and maturity as possible plant escape mechanisms from Sclerotinia stem rot in soybean $(18,20,24)$, but none have reported plant canopy as a possible Sclerotinia stem rot escape mechanism. Canopy architecture is also known to affect Sclerotinia stem rot severity in dry edible bean (26). All other agronomic values were inconsistently or not correlated with DSI in each MG (Table 11).

We reduced the chances of plants escaping Sclerotinia stem rot at the Urbana environment through continuous misting of these plots and two inoculations between the R1 and R7 growth stages. However, an environmental factor we were unable to control in our nursery was the temperature. S. sclerotiorum thrives under cool and moist environmental conditions; therefore, high summer temperatures probably reduced disease development $(17,20,27,28)$. Under intense disease severity, we observed a positive $(P<0.01)$ correlation between DSI and seed yield which was likely the result of the susceptible checks having higher seed yield than the PIs, which were not well adapted to the Urbana environment (Table 8).

The petiole inoculation technique did not have sufficient resolution to separate most resistant and susceptible check cultivars in the MG I and II tests. However, ratings from the petiole inoculation technique were predictive of field results in both the MG I and II tests and these correlations were higher than previous greenhouse and laboratory methods used for evaluating Sclerotinia stem rot $(2,7,19,23,24,27$; Table 12). The petiole inoculation technique may be testing physiological resistance, but additional studies are needed to verify this method and confirm that it correlates with field results across a wider array of germ plasm. If the petiole inoculation technique is measuring physiological resistance, it would be valuable for evaluating lines which may be escaping Sclerotinia stem rot in the field. For example, PI 507.353 had a low DSI value in the MG II test and had a short plant height (Table 9), but it

Table 12. Correlations between disease severity index values for Sclerotinia stem rot resistance and ratings from the excised leaf inoculation and petiole inoculation methods for each maturity group $(\mathrm{MG})^{\mathrm{a}}$

\begin{tabular}{lcc}
\hline MG & Excised leaf & Petiole inoculation \\
\hline 0 & 0.22 & $\ldots$ \\
I & 0.12 & $-0.58^{* *}$ \\
II & -0.05 & $-0.86^{* *}$ \\
III & $0.62^{*}$ & $\ldots$ \\
IV & 0.41 & $\ldots$ \\
\hline
\end{tabular}

${ }^{a}$ Correlation coefficients are calculated with disease severity index (DSI) values across 13 replications for 18 entries in the MG 0 test, across 21 replications for 22 entries in the MG I test, across 14 replications for 9 (excised leaf) or 8 (petiole inoculation) entries for the MG II test, across six replications for 11 entries in the MG III test, and across four replications for 14 entries in the MG IV test. The DSI values were correlated against the mean of four replications for the excised leaf test and the mean of four replications across two experiments for the petiole inoculations; $*$ and $* *=$ significant at the 0.05 and 0.01 probability level, respectively.
Table 13. Origins of the 68 maturity group (MG) 0 to IV soybean plant introductions identified as partially resistant to Sclerotinia stem rot in field evaluations

\begin{tabular}{|c|c|c|}
\hline MG & $\begin{array}{l}\text { Plant intro- } \\
\text { duction }\end{array}$ & Country of origin \\
\hline 0 & PI 089.001 & China \\
\hline 0 & PI 132.207 & Netherlands \\
\hline 0 & PI 153.259 & Belgium \\
\hline 0 & PI 189.861 & Germany \\
\hline 0 & PI 189.899 & France \\
\hline 0 & PI 232.996 & Germany \\
\hline 0 & PI 243.547 & Japan \\
\hline 0 & PI 291.319B & China \\
\hline 0 & PI 361.059B & China \\
\hline 0 & PI 417.449 & Japan \\
\hline 0 & PI 417.507 & Germany \\
\hline 0 & PI 417.533 & Germany \\
\hline 0 & PI 437.072 & Russian Federation \\
\hline 0 & PI 437.527 & Ukraine \\
\hline 0 & PI 437.764 & China \\
\hline 0 & PI 438.267 & China \\
\hline 0 & PI 548.354 & China \\
\hline 0 & PI 548.404 & Canada \\
\hline 0 & PI 548.539 & Canada \\
\hline 0 & PI 567.157A & China \\
\hline 0 & PI 578.501 & China \\
\hline I & FC 030.233 & Canada \\
\hline I & PI 081.775 & Japan \\
\hline I & PI 091.733 & China \\
\hline I & PI 153.282 & Belgium \\
\hline I & PI 153.316 & France \\
\hline I & PI 184.042 & Yugoslavia \\
\hline I & PI 189.896 & Germany \\
\hline I & PI 189.919 & France \\
\hline I & PI 391.589B & China \\
\hline I & PI 416.776 & Japan \\
\hline I & PI 416.805 & Japan \\
\hline I & PI 427.143 & South Korea \\
\hline I & PI 504.502 & Taiwan \\
\hline I & PI 548.312 & China \\
\hline I & PI 548.380 & China \\
\hline I & PI 548.407 & Japan \\
\hline I & PI 549.066 & Japan \\
\hline I & PI 561.284 & China \\
\hline I & PI 561.331 & China \\
\hline I & PI 561.345 & China \\
\hline I & PI 561.353 & China \\
\hline I & PI 561.367 & China \\
\hline II & PI 189.931 & France \\
\hline II & PI 358.318A & Japan \\
\hline II & PI 507.352 & Japan \\
\hline II & PI 507.353 & Japan \\
\hline III & PI 196.157 & Japan \\
\hline III & PI 229.324 & Japan \\
\hline III & PI 398.637 & South Korea \\
\hline III & PI 404.180 & China \\
\hline III & PI 417.201 & Japan \\
\hline III & PI 423.818 & South Korea \\
\hline IV & PI 417.245 & Japan \\
\hline IV & PI 506.519 & Japan \\
\hline IV & PI 506.652 & Japan \\
\hline IV & PI 506.654 & Japan \\
\hline IV & PI 506.728 & Japan \\
\hline IV & PI 506.733A & Japan \\
\hline IV & PI 506.784 & Japan \\
\hline IV & PI 506.868 & Japan \\
\hline IV & PI 506.892 & Japan \\
\hline IV & PI 507.222 & Japan \\
\hline IV & PI 561.388 & Japan \\
\hline IV & PI 567.650B & China \\
\hline IV & PI 567.721 & China \\
\hline IV & PI 594.286 & Japan \\
\hline IV & PI 594.289 & Japan \\
\hline
\end{tabular}


had the greatest resistance rating in the petiole inoculation technique (Table 5). Our excised leaf inoculation method results were not as consistent with field results as those found by Kim et al. (19). We found that field DSI ratings were significantly correlated with excised leaf inoculation results in only one of five of our MG field tests, whereas Kim et al. (19) observed a significant correlation in 1 group of 18 soybean genotypes. The excised leaf inoculation method has the advantage of testing of plant tissue in greenhouse, growth chamber, or field plants under a constant environment. The lack of significant correlation between DSI and results from the excised leaf inoculation method may be caused by the genotypes used in our study. Kim et al. (19) used genotypes with a wide diversity in resistance levels, and we used genotypes that were mostly resistant. The skewing of our genotypes to high levels of resistance likely caused significant correlations to be more difficult to obtain.

Identifying PIs with equal or better levels of resistance to Sclerotinia stem rot and similar agronomic traits to modern cultivars is critical. PIs 153.282 and 561.331 for the MG I test, PI 189.931 for the MG II test, and PIs 196.157, 398.637, 417.201, and 423.818 in the MG III tests were agronomically similar to the checks and had high levels of resistance (Tables 8 to 10). These MG I to III PIs should be the most useful to soybean breeders who are trying to improve the level of Sclerotinia stem rot resistance. When these PIs are hybridized with the elite cultivars, the populations should have less segregation for agronomic traits than other PIs we identified with partial resistance.

The USDA Soybean Germplasm Collection has been evaluated for new sources of resistance to other diseases like brown stem rot (Phialophora gregata (Allington \& D. W. Chamberlain) W. Gams), Phytophthora root rot (Phytophthora sojae (M. J. Kaufmann and J. W. Gerdemann)), and Rhizoctonia root rot (Rhizoctonia solani Kühn) $(1,4,22)$, but the collection has not been evaluated previously for Sclerotinia stem rot resistance. Our study was an intensive effort by 16 researchers in eight institutions to identify sources of Sclerotinia stem rot resistance that should be useful in increasing the level of resistance in our current germ plasm. We identified 68 MG 0 to IV PIs originating from 12 countries, with 26 originating from Japan and 21 originating from China (Table 13). Breeders should be able to utilize these PIs to incorporate new sources of Sclerotinia stem rot resistance into their elite cultivars. These sources of resistance in soybean should be beneficial in controlling Sclerotinia stem rot in the United States and other countries where this disease is a problem.

\section{ACKNOWLEDGMENTS}

We thank T. Cary, D. Thomas, and C. Greer for their assistance in designing and assembling the irrigation system used in the Sclerotinia stem rot nursery at the University of Illinois at UrbanaChampaign; Stine Seed Co., Dairyland Seed Co., Inc., Asgrow Seed Co., and Pioneer Hi-Bred Int., Inc. for testing the PIs in 1995 to 1997; L. Kull, J. J. Manandhar, C. Weeks, and T. Vuong for assistance in producing the inoculum; and graduate student J. Auclair for setting up field trials and collecting DSI in the Sclerotinia stem rot nursery at Elora, Ontario.

\section{LITERATURE CITED}

1. Bachman, M. S., Nickell, C. D., Stephens, P. A., and Nickell, A. D. 1997. Brown stem rot resistance in soybean germplasm from central China. Plant Dis. 81:953-956.

2. Boland, G. J., and Hall, R. 1986. Growthroom evaluation of soybean cultivars for resistance to Sclerotinia sclerotiorum. Can. J. Plant Sci. 66:559-564.

3. Boland, G. J., and Hall, R. 1988. Epidemiology of Sclerotinia stem rot of soybean in Ontario. Phytopathology 78:1241-1245.

4. Bradley, C. A., Hartman, G. L., Nelson, R. L., Mueller, D. S., and Pedersen, W. L. Response of ancestral soybean lines and commercial cultivars to Rhizoctonia root and hypocotyl rot. Plant Dis. 85:1091-1095.

5. Carpenter, M. A., Frampton, C., and Stewart A. 1999. Genetic variation in New Zealand populations of the plant pathogen Sclerotinia sclerotiorum. N. Z. J. Crop Hortic. Sci. 27:1321.

6. Chamberlain, D. W. 1951. Sclerotinia stem rot of soybeans. Plant Dis. Rep. 35:490-491.

7. Chun, D., Kao, L. B., and Lockwood, J. L. 1987. Laboratory and field assessment of resistance in soybean to stem rot caused by Sclerotinia sclerotiorum. Plant Dis. 71:811815.

8. Del Rio, L., Kurtzweil, N. C., and Grau, C. R. 2000. Petiole inoculation as a tool to screen soybean germ plasm for resistance to Sclerotinia sclerotiorum. (Abstr.) Phytopathology: 91:S176.

9. Doupnik, B. 1993. Soybean production and disease loss estimates for north central United States from 1989 to 1991. Plant Dis. 77:11701171.

10. Fehr, W. R., Caviness, C. E., Burmood, D. T., and Pennington, J. S. 1971. Stage of development descriptions for soybeans, Glycine max (L.) Merrill. Crop Sci. 11:929-931.

11. Grau, C. R. 1988. Sclerotinia stem rot of soybean. Pages 55-56 in: Soybean Diseases of the North Central Region. T. D. Wyllie and D. H. Scott, eds. American Phytopathological Society Press, St. Paul, MN.

12. Grau, C. R., Adee, E. A., and Oplinger, E. S. 1994. An integrated approach to control Sclerotinia stem rot (White Mold) in soybean. Pages 183-196 in: Proc. Integrated Crop Manag. Conf. Ames, IA.
13. Grau, C. R., and Bissonnette, H. L. 1974 Whetzelinia stem rot of soybean in Minnesota. Plant Dis. Rep. 59:693-695.

14. Grau, C. R., and Radke, V. L. 1984. Effects of cultivars and cultural practices on Sclerotinia stem rot of soybean. Plant Dis. 68:56-58.

15. Grau, C. R., Radke, V. L., and Gillespie, F. L. 1982. Resistance of soybean cultivars to Sclerotinia sclerotiorum. Plant Dis. 66:506-508.

16. Hartman, G. L., Kull, L., and Huang, Y. H. 1998. Occurrence of Sclerotinia sclerotiorum in soybean fields in east-central Illinois and enumeration of inocula in soybean seed lots. Plant Dis. 82:560-564.

17. Hoffman, D. D., Hartman, G. L., Mueller, D. S., Leitz, R. A., Nickell, C. D., and Pedersen, W. L. 1998. Yield and seed quality of soybean cultivars infected with Sclerotinia sclerotiorum. Plant Dis. 82:826-829.

18. Kim, H. S., and Diers, B. W. 2000. Inheritance of partial resistance to Sclerotinia stem rot in soybean. Crop Sci. 40:55-60.

19. Kim, H. S., Hartman, G. L., Manandhar, J. B., Graef, G. L., Steadman, J. R., and Diers, B. W. 2000. Reaction of soybean cultivars to Sclerotinia stem rot in field, greenhouse, and laboratory evaluations. Crop Sci. 40: 665-669.

20. Kim, H. S., Sneller, C. H., and Diers, B. W. 1999. Evaluation of soybean cultivars for resistance to Sclerotinia stem rot in field environments. Crop Sci. 39:64-68.

21. Kull, L. S., Pedersen, W. L., and Hartman, G. L. 2001. Clonality and aggressiveness of Sclerotinia sclerotiorum. Pages 23-24 in: Proc. XIth Int. Sclerotinia Workshop, York, UK.

22. Kyle, D. E., Nickell, C. D., Nelson, R. L., and Pedersen, W. L. 1998. Response of soybean accessions from provinces in southern Chin to Phytophthora sojae. Plant Dis. 82:555-559.

23. Nelson, B. D., Helms, T. C., and Kural, I. 1991. Effects of temperature and pathogen isolate on laboratory screening of soybean for resistance to Sclerotinia sclerotiorum. Can. J. Plant Sci. 71:347-352.

24. Nelson, B. D., Helms, T. C., and Olson, M. A. 1991. Comparison of laboratory and field evaluations of resistance in soybean to Sclerotinia sclerotiorum. Plant Dis. 75:662-665.

25. Pennypacker, B. W., and Risius, M. L. 1999. Environmental sensitivity of soybean cultivar response to Sclerotinia sclerotiorum. Phytopathology 89:618-622.

26. Steadman, J. R. 1983. White mold-a serious yield-limiting disease of bean. Plant Dis. 67:346-350.

27. Wegulo, S. N., Yang, X. B., and Martinson, C. A. 1998. Soybean cultivar responses to Sclerotinia sclerotiorum in field and controlled environment studies. Plant Dis. 82:1264-1270.

28. Workneh, F., and Yang, X. B. 2000. Prevalence of Sclerotinia stem rot of soybeans in the north-central United States in relation to tillage, climate, and latitudinal positions. Phytopathology 90:1375-1382.

29. Wrather, J. A., Stienstra, W. C., and Koenning, S. R. 2001. Soybean disease loss estimates for the United States from 1996 to 1998. Can. J. Plant Pathol. 23:122-131.

30. Yang, X. B., Lundeen, P., and Uphoff, M. D. 1999. Soybean varietal response and yield loss caused by Sclerotinia sclerotiorum. Plant Dis. 83:456-461. 